\title{
Feasibility of different harvesting strategies and economies of scale in ranching wild cod (Gadus morhua)
}

\author{
Jón E. Halldórsson, Björn Björnsson, Stefán B. Gunnlaugsson ${ }^{1}$
}

\begin{abstract}
The effects of different harvesting strategies and increased fish biomass on the feasibility of ranching wild cod in 'herds' formed with anthropogenic feeding were studied. The five following scenarios using purse seine as the method of capture were considered: I. Basic harvesting, II. Harvesting with size-grading and selling the smaller cod for on-growing, III. Harvesting with size-grading and on-growing the smaller cod in sea cages within the company, IV. Intensive harvesting at the end of the growth period, and V. Ranching larger biomass with basic harvesting. For basic harvesting it is assumed that wild cod are fully fed at several feeding stations for 165 days per year and harvested three days a week from September 1 to November 5 without size-grading. It is also assumed that the ranching company owns a suitable fishing vessel and cod quota, 200 tons in Scenarios I-IV and 500 tons in Scenario V. For a 15 year operating period, the net present value (NPV) for the five scenarios is $€ 754000, € 809000, € 819000, € 700000$ and $€ 1504000$, respectively. Cod ranching is viable in all scenarios but the size of the operation has much greater effect than the harvesting strategy on the feasibility. Although intensive aquaculture will continue to grow globally, well managed fish stocks will always be an important food source for mankind and thus ranching, which basically is a quota multiplier, can increase this food supply, potentially at competitive prices.
\end{abstract}

\section{Ágrip}

Könnuð voru áhrif mismunandi uppskeruskipulags og aukinnar lífpyngdar á hagkvæmni hjarðeldis á villtum porski sem safnað er saman í hjarðir með reglubundinni fóðrun. Fimm eftirfarandi sviðsmyndir sem allar byggja á veiðum með hringnót voru teknar til athugunar: I. Grunnskipulag, II. Grunnskipulag með stærðarflokkun á fiski og sölu á smáfiski til áframeldis, III. Grunnskipulag með stærðarflokkun á fiski og áframeldi á smáfiski í sjókvíum innan fyrirtækis, IV. Grunnskipulag með söfnun á fiski á aðeins tveimur vikum í lok vaxartíma, V. Grunnskipulag með meiri lífpyngd. Grunnskipulagið gerir ráð fyrir að villtur porskur sé vel fóðraður á allmörgum fóðrunarstöðvum í 165 daga á ári og veiddur prjá daga í viku í samtals 9 vikur í lok fóðrunartímabils. Gert er ráð fyrir and hjarðeldisfyrirtækið eigi heppilegan bát og porskkvóta, 200 tonn í sviðsmyndum I-IV og 500 tonn í sviðsmynd V. Fyrir 15 ára rekstrartímabil, er núvirðið (NPV) fyrir hin mismunandi sviðsmyndir, €754 000, €809 000, €819 000, €700 000 og €1 504 000, í sömu röð. Hjarðeldið er hagkvæmt fyrir allar sviðsmyndirnar en umfang eldisins

\footnotetext{
1 The first author finished a MSc. degree in Natural Resource Sciences at the University of Akureyri in spring 2009. The paper is based on his thesis. The second author is a senior scientist at Marine Research Institute, Reykjavík. He is the corresponding author bjornb@hafro.is. The third author is a docent at the University of Akureyri.
} 
hefur mun meiri áhrif en uppskeruskipulagið á hagkvæmnina. •́́ að pauleldi muni halda áfram að vaxa á heimsvísu munu hóflega nýttir fiskistofnar alltaf verða mikilvæg fæðuuppspretta fyrir mannkyn og pví getur hjarðeldi sem kvótaaukandi aðgerð aukið pessa fæðuuppsprettu hafsins, mögulega á hagkvæman hátt.

JEL classification codes: Q22

Keywords: cod ranching, feasibility, harvesting strategies, profitability, sea ranching, stock enhancement

\section{Introduction}

Stock enhancement and sea ranching is a well known fisheries management approach, involving the release of cultured organisms to increase abundance and yield of natural fish or invertebrate stocks (Blaxter 2000; Lorenzen 2005). Recruitment limitation is the theoretical basis for stock enhancement in marine and freshwater populations (Doherty 1999; Lorenzen 2005). Juveniles of number of species have been released for experimental and commercial purposes, e.g. black sea bream (Acanthopagrus schlegelii) (Gonzalez, Umino \& Nagasawa 2008), red sea bream (Pagrus major) and Japanese flounder (Paralichthys olivaceus) (Kitata \& Kishino, 2006). In Norway, more than one million tagged juvenile Atlantic cod (Gadus morhua L.) were released in the years 1983-96 without significantly increasing cod production and catches (Svåsand et al. 2000).

In areas where there is overabundance of young fish with respect to the available food supply the growth rate and fish production can be increased in 'herds' of wild fish formed and maintained with sufficient anthropogenic feeding (Björnsson 2001; 2002; 2011). A 17 month long ranching experiment carried out in the years 1995-96 in Stödvarfjördur, a small fjord in East Iceland, showed that a large number of free ranging wild cod could be conditioned to feed on trash fish provided at specific locations (Björnsson 1999) and the yearly weight gain of the conditioned cod increased about three-fold (Björnsson 2002). A feasibility study based on this experiment indicated that fjord ranching could be more profitable than full-cycle farming in sea cages or land based tanks (Knútsson 1997).

To further develop ranching of wild cod in 'herds' a 21 month ranching experiment was carried out in Arnarfjördur a large fjord in Northwest Iceland in the years 2005-2006. A new feeding method was developed to minimize feed waste and a new technique initiated to capture cod at the four feeding stations (Björnsson 2011). Recaptures of cod tagged at the feeding stations showed high fidelity to the herds during the main growth period from early summer to fall (Björnsson, et al. 2010). A feasibility study based on this experiment was carried out to evaluate four different scenarios for an existing fishing company to utilize it's 200 ton cod quota: (1) ranching in herds, (2) farming in sea cages, (3) selling the quota and invest in fullcycle cod farming or (4) catching the cod at a mean weight of about $2 \mathrm{~kg}$ as is currently practiced. The results indicate that ranching is the most feasible scenario, traditional fishing the second most feasible scenario, but with the least risk involved, whereas full-cycle farming is presently unrewarding (Halldórsson et al. 2012).

The present paper is a follow-up study in which the feasibility of five different scenarios of cod ranching in 'herds' are compared. The word 'herd' is used to emphasize the anthropogenic aspect of the operation. In one scenario larger biomass and in the other scenarios different harvesting strategies are assumed, such 
as size-grading the harvest, on-growing the undersized fish in sea cages and shortening the harvesting period.

Table 1. Base-line assumptions used in the feasibility study

\begin{tabular}{|c|c|c|}
\hline & Value & Reference: \\
\hline Cod quota (ton) & 200 & \\
\hline FCR & 3.2 & Gunnarsson et al. 2009 \\
\hline $\begin{array}{l}\text { Operating period } \\
\text { (years) }\end{array}$ & 15 & \\
\hline Discount rate $(\%)$ & 20 & \\
\hline $\begin{array}{l}\text { Total mortality ( } \% \\
\text { of initial number) }\end{array}$ & 5.0 & \\
\hline $\begin{array}{l}\text { Initial mean weight } \\
(\mathrm{kg})\end{array}$ & 2.0 & \\
\hline $\begin{array}{l}\text { Final mean weight } \\
(\mathrm{kg})\end{array}$ & $3.2-6.4$ & \\
\hline $\begin{array}{l}\text { Growth rate } \\
\text { (\%/day) }\end{array}$ & 0.48 & Björnsson 2011 \\
\hline $\begin{array}{l}\text { Market price of cod } \\
(€ / \mathrm{kg})\end{array}$ & $1.62-2.06$ & Verdlagsstofa skiptaverds, 2008 \\
\hline Type of feed & Capelin & \\
\hline Fishing gear & Purse seine & \\
\hline Price of feed $(€ / \mathrm{kg})$ & 0.23 & $\begin{array}{l}\text { Sindri Sigurdsson, Síldarvinnslan Ltd., personal } \\
\text { communication. }\end{array}$ \\
\hline $\begin{array}{l}\text { Transportation and } \\
\text { storage of feed } \\
(€ / \mathrm{kg})\end{array}$ & 0.16 & $\begin{array}{l}\text { Sindri Vidarsson, Vinnslustödin Ltd., personal } \\
\text { communication. } \\
\text { Kristján G. Jóakimsson, Hradfrysthúsid- } \\
\text { Gunnvör Ltd., personal communication. }\end{array}$ \\
\hline Other expenses (\%) & 10 & \\
\hline Oil price $(€ /$ litre $)$ & 0.63 & $\begin{array}{l}\text { Atli Ingvarsson, N1 Ltd., personal } \\
\text { communication }\end{array}$ \\
\hline
\end{tabular}

\section{Methods}

Profit calculations were performed assuming that an existing fishing company owns a fishing vessel (30 GRT) suitable for ranching of wild cod in herds and either 200 or 500 tons of cod quota. It was also assumed that the company has exclusive rights over a sufficiently large coastal area with wild cod to carry out ranching. This means that fishing in that area is prohibited by others during the leasing time. In these calculations no extra fee for the exclusive rights was assumed. The ranching operation will involve forming several feeding stations where frozen trash fish, such as capelin (Mallotus villosus), is supplied in net bags according to biomass and appetite of the fish (Björnsson 2011). The fish will be attracted to the feeding stations in spring with daily feeding gradually increasing on demand. Subsequently, during a 165 day long growth period each summer, feed will be provided three times a week. The fish will be harvested in autumn with a purse seine before they start to migrate away from the feeding stations (Björnsson et al. 2010). The assumptions about fish size, growth rate, feed conversion ratio (FCR $=\mathrm{kg}$ feed $/ \mathrm{kg}$ growth), mortality, price of fish, discount rate, cost of feed and equipment etc. (Table 1) are the 
same as in an earlier study (Halldórsson et al. 2012). It was assumed in the calculations that depreciation of investments per year was $12 \%$ for the alterations of the boat; $10 \%$ for the feeding equipment, forklift, sea pens and lift net; $7 \%$ for the purse seine; and $4 \%$ for the freezer plant built for Scenario V. Tax ratio, interest rates or financial costs were not included in the profit calculations. Quota efficiency is defined as the ratio of the harvested volume and the quota used for ranching, i.e. the final biomass divided by the initial biomass of the ranched fish. A series of sensitivity analyses was carried out for the parameters most influential on the profitability of cod ranching: FCR, growth rate, price of feed, price of cod and capture success of conditioned cod. The net present value (NPV) after tax and depreciation for a 15 year operating period was used as a measure of profitability. Icelandic currency was converted to Euros at the exchange rate of 150 ISK/€, February 4, 2009 (Central Bank of Iceland 2009). The discount rate was set at $20 \%$ as cod ranching is considered risky, since it is still an unproven operational form.

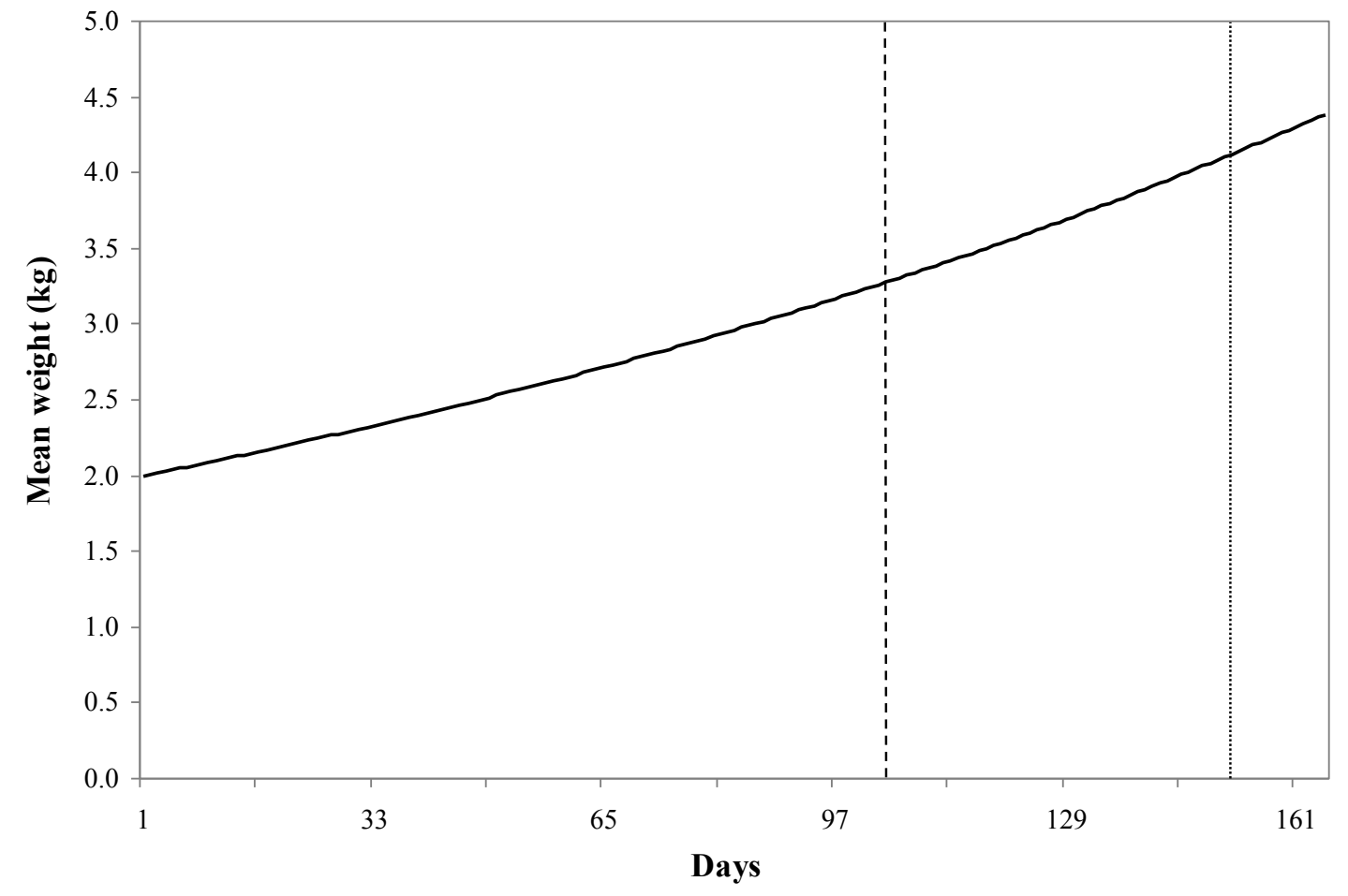

Fig. 1. Mean weight $(\mathrm{kg})$ of cod in herds during the main growing period, May 25 to November 5 . The growth rate during the 165 day period is assumed to be $0.48 \%$ per day. The dashed line indicates the beginning of the 9 week harvesting period (Scenarios I-III and V) and dotted line the beginning of the 2 week harvesting period (Scenario IV).

\section{Basic harvesting}

This scenario is the same as presented in a published paper in which the feasibility of cod ranching is compared to commercial fishing of cod and cod farming (Halldórsson et al. 2012). Cod quota of 200 tons are ranched from spring until autumn and the capturing assumed to take place from September 1 to November 5, three days a week, 3300 fish captured each time with a purse seine, bled and iced onboard and brought to the fish market. There is no size-grading and the average 
weight of the catch corresponds to the average weight of the herd fish, increasing from 3.2 to $4.3 \mathrm{~kg}$ during the 9 week harvesting period (Fig. 1, Table 2).

\section{Harvesting with size-grading}

As in Scenario I, the harvesting period is from the beginning of September to early November and every three days a week 3300 cod are caught with a purse seine. The only difference from Scenario I is that the catch in Scenario II is size-graded during the entire harvesting period. It is assumed that cod smaller than $2.5 \mathrm{~kg}$ are transported alive to sea cages provided by an on-growing company and sold at a price $10 \%$ higher than the market price of dead cod. The average weight of small cod is $1.8 \mathrm{~kg}$ and the corresponding market price $1.45 € / \mathrm{kg}$ including markup. For this scenario, minor adjustments to the vessel must be made in order to transport live cod. Expected cost of such adjustments is $€ 46667$ (Aasjord \& Hansen 2006).

Table 2. The different assumptions used in the five scenarios

\begin{tabular}{|c|c|c|c|c|c|}
\hline & I & II & III & IV & $\mathbf{V}$ \\
\hline $\begin{array}{l}\text { Number of } \\
\text { herds }\end{array}$ & 8 & 8 & 8 & 8 & 20 \\
\hline Man-years & 3 & 3 & 3 & 3 & 5 \\
\hline Salaries $(€ / y)$ & 83333 & 83333 & 83333 & 83333 & 130000 \\
\hline Catch $(\operatorname{cod} / d)$ & 3300 & 3300 & 3300 & 9500 & 5000 \\
\hline $\begin{array}{l}\text { Harvesting } \\
\text { period (weeks) }\end{array}$ & 9 & 9 & 16 & 2 & 9 \\
\hline $\begin{array}{l}\text { Chartered } \\
\text { vessel }\end{array}$ & No & No & No & Yes & Yes \\
\hline $\begin{array}{l}\text { Total } \\
\text { investments } \\
(€ / y)\end{array}$ & 314667 & 361333 & 507999 & 394667 & 1027610 \\
\hline
\end{tabular}

\section{Harvesting with size-grading and on-growing}

In this scenario the method of size-grading is the same as in Scenario II, i.e. $3300 \mathrm{cod}$ are caught every fishing day, three times a week, and cod smaller than $2.5 \mathrm{~kg}$ transported to sea cages, but in this scenario the ranching company itself grows the cod for another year to extend the harvesting period. The mean initial weight of small cod for on-growing is the same as in Scenario II, $1.8 \mathrm{~kg}$. During the period from September to January the FCR is assumed to be the same as in ranching and conventional on-growing of cod (3.2), but during the second year of farming the FCR rises to 4.0, which is similar as in on-growing of cod during the second and third year of farming in Iceland in 2007 (Gunnarsson et al. 2009). Growth rates during the second year of on-growing are estimated with a growth model for cod (Björnsson et al. 2007). Cost of vessel adjustment is the same as in Scenario II and it is assumed that three sea cages are purchased during the first year. Two of those have a circumference of $90 \mathrm{~m}$ and the corresponding volume is approximately $9000 \mathrm{~m}^{3}$. The third is a smaller cage used during size-grading of the herd fish. Total investments of sea cages, including deployment, are $€ 73000$ and the durability of the net is five years (Kristján G. Jóakimsson, Hradfrystihúsid-Gunnvör Ltd., personal communication). Regular maintenance, i.e. cleaning and repairing of the nets is performed at a cost of $€ 6700$ every other year (Sævar Th. Ásgeirsson, Brimcodfarming Ltd., personal communication). Other maintenance cost of sea cages is 
assumed to be $7 \%$ of accumulated investments in cages. It is anticipated that the two large cages are being filled from September 1 until November 5 and harvested in November (mean wt. $6.4 \mathrm{~kg}$ ) and December (mean wt. $6.2 \mathrm{~kg}$ ) in the following year.

\section{Intensive harvesting at the end of the growth period}

By suspending harvesting until late October, one can maximize the total growth of the herds. In this scenario, it is assumed that all fishing takes place during the last two weeks of the growth period (Fig. 1) five days a week with a daily catch of 9500 cod. Since captured volume of every fishing day is beyond the capacity of the current fishing vessel it will be necessary to charter a boat of similar size during the two week harvesting period. For the second vessel, a similar fishing gear is assumed to be purchased by the ranching company. The expected cost of chartering is assumed to be $0.17 € / \mathrm{kg}$.

\section{Ranching larger biomass with basic harvesting}

In this scenario it is assumed that the company owns 500 tons of cod quota and establishes 20 feeding stations instead of 200 ton quota and 8 feeding stations as assumed in Scenarios I-IV. This would of course require exclusive rights of a larger coastal area, e.g. the whole of Arnarfjördur Northwest Iceland instead of only part of the fjord (Björnsson 2011). It is assumed to be necessary to charter a larger boat, about 60 GRT, to take care of fishing from the herds in the period SeptemberNovember. The cost of chartering a boat is assumed to be $0.17 € / \mathrm{kg}$, the same as in Scenario IV, which should be reasonable because although this scenario requires more man-power, the boat is allowed to catch greater quantities and the fishing is assumed to take place during five days a week with 5000 cod caught per day.

For this scenario it is assumed to be necessary to build a $1800 \mathrm{~m}^{3}$ freezer plant near the ranching area to store frozen feed. The cost of an insulated steel frame building is assumed to be $€ 482000$ and the freezing equipment $€ 178000$ whereas the cost of electricity required to run the freezer facility in Northwest Iceland is assumed to be $€ 6000$ on an annual basis $(250000 \mathrm{kWh} \times 0.024 € / \mathrm{kWh}$, Westfjord Power Company Ltd. 2008).

\section{Results}

\section{Basic harvesting}

This scenario delivers a total of 361 tons of cod per year from the initial quota of 200 tons providing operating revenues of $€ 614000$ per year and quota efficiency of 1.81. Feed and transportation of feed amount to $31 \%$ and $18 \%$ of the operating expenses, respectively, and salaries $20 \%$. Total production cost for harvested cod is on average $1.15 € / \mathrm{kg}$ and operating expenses $€ 414000$ per year (Table 3). Basic harvesting generates net profits of $€ 150000$ per year and the cash flow analysis indicates that cod ranching is cost-efficient with the net present value (NPV) of $€ 754000$. Calculations based on the operating statement indicate a profit margin of $24.4 \%$.

\section{Harvesting with size-grading}

Annually this scenario delivers 314 tons of 69780 large cod to fish market and 47 tons of 25960 small cod are sold alive for on-growing in sea cages with equal quota efficiency as in Scenario I. The average weight of cod sold on the market is $4.1 \mathrm{~kg}$ in the first week, rising to $4.9 \mathrm{~kg}$ in the last week of harvesting. The operating revenues 
are $€ 633000$ per year and the production cost $1.14 € / \mathrm{kg}$. The profit margin is $26.5 \%$ and the NPV €809 000 (Table 3).

\section{Harvesting with size-grading and on-growing}

As in Scenario II, 47 tons of small cod are transferred to sea cages every year but in this scenario the on-growing of the fish is an integral part of the ranching operation. From the second year onward, the annual volume of harvested cod is 470 tons, resulting in a quota efficiency of 2.35 and average revenues generated from sales are $€ 861000$ per year. Since on-growing of cod for a second year results in a higher FCR due to sexual maturity, feed and feed related costs constitute a considerably larger proportion of the expenses. Purchase of feed accounts for $35 \%$ of the expenses, and when storage and transportation costs have been added, the total feed related costs amount to $59 \%$ of the operating expenses. The operation is profitable with a profit margin of $22.8 \%$ and NPV of $€ 819000$ (Table 3). On-growing the small cod for a second year results in a production cost of $1.31 € / \mathrm{kg}$, the highest for all scenarios. Despite the high production cost, this scenario is considered a feasible option because of high quota efficiency, extended harvesting period and the synergistic effects of ranching vs. on-growing in sea cages.

Table 3. Summary of the economic results and key parameters for the five scenarios

\begin{tabular}{|c|c|c|c|c|c|}
\hline & $\mathbf{I}$ & II & III & IV & $\mathbf{V}$ \\
\hline Quota efficiency & 1.81 & 1.81 & 2.35 & 2.03 & 1.81 \\
\hline $\begin{array}{l}\text { Operating revenues } \\
(€ / y)\end{array}$ & 614444 & 633100 & 860861 & 715624 & 1542910 \\
\hline $\begin{array}{l}\text { Operating expenses } \\
(€ / y)\end{array}$ & 414452 & 410919 & 600251 & 510817 & 1056351 \\
\hline EBITDA $(€ / y)$ & 199992 & 222181 & 260610 & 204807 & 486559 \\
\hline $\begin{array}{l}\text { Net operating profits } \\
(€ / y)\end{array}$ & 149635 & 167830 & 196336 & 149500 & 363356 \\
\hline $\operatorname{NPV}(€)$ & 753692 & 809109 & 819064 & 699896 & 1503996 \\
\hline Profit margin $(\%)$ & 24.4 & 26.5 & 22.8 & 20.9 & 23.6 \\
\hline $\begin{array}{l}\text { Feed requirement }(\mathrm{kg} \\
\text { per harvested } \mathrm{kg})\end{array}$ & 1.44 & 1.44 & 1.69 & 1.63 & 1.44 \\
\hline Oil consumption $(1 / \mathrm{kg})$ & 0.07 & 0.07 & 0.13 & 0.04 & $0.04^{1}$ \\
\hline $\begin{array}{l}\text { Production (ton/man- } \\
\text { year) }\end{array}$ & 54 & 54 & 86 & 69 & 81 \\
\hline $\begin{array}{l}\text { Feeding } \operatorname{cost}^{2}(€ / \mathrm{kg} \\
\text { harvested })\end{array}$ & 0.60 & 0.60 & 0.78 & 0.67 & 0.56 \\
\hline $\begin{array}{l}\text { Salaries }(€ / \mathrm{kg} \\
\text { harvested) }\end{array}$ & 0.23 & 0.23 & 0.18 & 0.21 & 0.14 \\
\hline $\begin{array}{l}\text { Production cost }(€ / \mathrm{kg} \\
\text { harvested) }\end{array}$ & 1.15 & 1.14 & 1.31 & 1.26 & 1.17 \\
\hline
\end{tabular}

${ }^{1}$ Excluding capturing. ${ }^{2}$ Including transportation and storage.

\section{Intensive harvesting at the end of the growth period}

In this scenario, all of the fish are captured during the last two weeks of the growth period yielding 406 tons annually resulting in a quota efficiency of 2.03. Mean weight $(4.25 \mathrm{~kg})$ and price $(1.76 € / \mathrm{kg})$ of harvested cod is also greater because of suspended harvesting. Total operating revenues generated from sales are $€ 716000$ per year. The 
cost of feed, transportation of feed and storage of feed amount to $32 \%, 18 \%$ and $4 \%$, respectively. The expenditure of chartering a vessel accounts for 7\%. Production cost for this scenario is $1.26 € / \mathrm{kg}$. The NPV and the profit margin are the lowest for this scenario (Table 3 ).

\section{Ranching larger biomass with basic harvesting}

This scenario is the same as Scenario I except that the annual cod quota is 500 instead of 200 tons. The quota efficiency is the same, 1.81, but the total harvest is much greater, 906 tons and average revenues $€ 1543000$ per year. As before, the main cost items are the feed and transportation of feed, 30 and 17\% of the expenses, but the storage cost of feed has fallen from 4 to $1 \%$ from previous scenarios, since the company is operating its own freezing facility. The cost of chartering a vessel for capturing is $€ 151000$ a year amounting to $14 \%$ of operating expenses. The production cost for larger scale ranching is $1.17 € / \mathrm{kg}$ and the profit margin $23.6 \%$. The operation is the most profitable of the five alternatives with the NPV of $€ 1504$ 000 (Table 3).

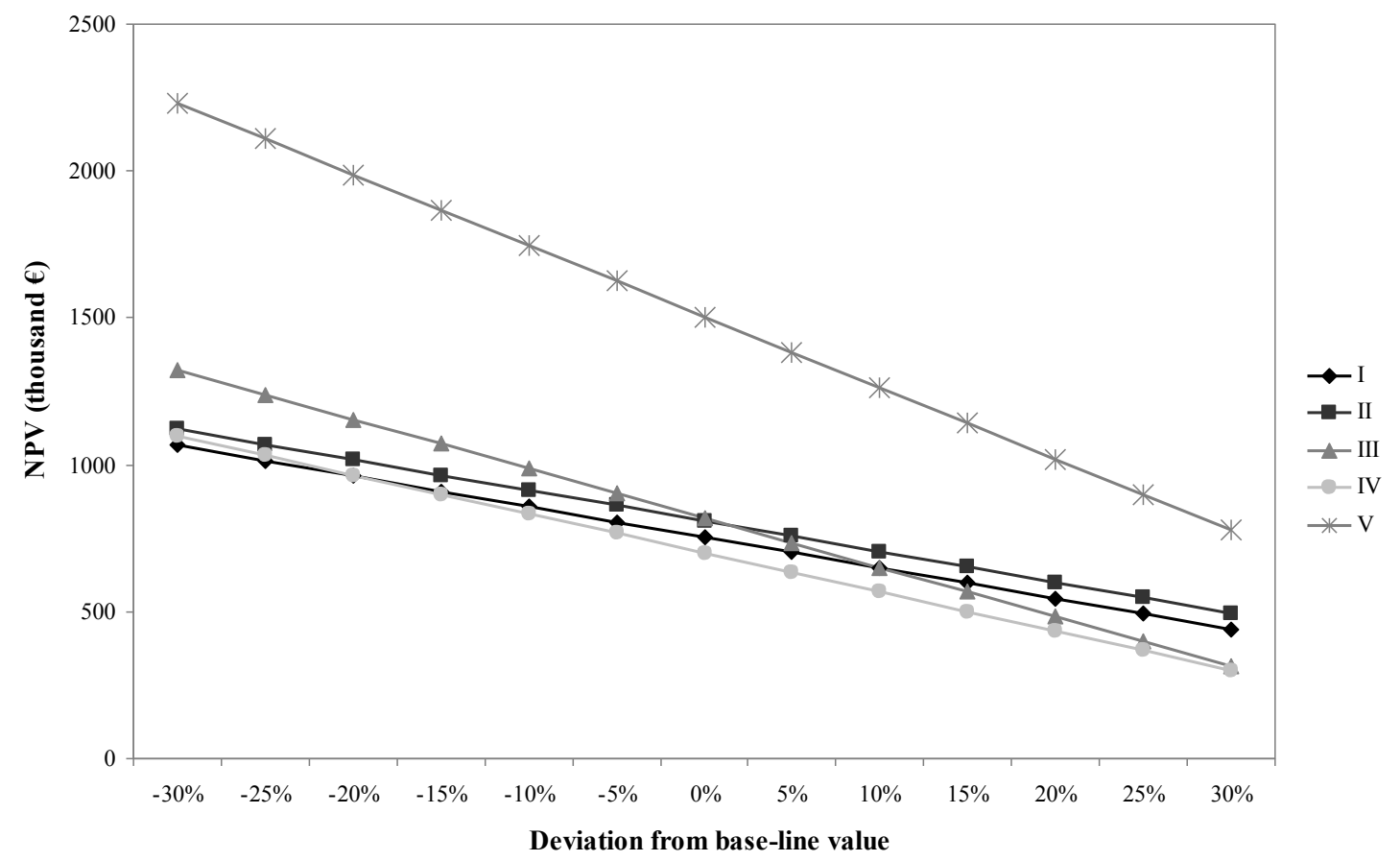

Fig. 2. Sensitivity in NPV to changes in FCR from the base-line value of $3.2 \mathrm{~kg} / \mathrm{kg}$ for the five different scenarios.

\section{Sensitivity analysis}

An increase in FCR means that more feed is given for the same production of fish. A $30 \%$ increase in FCR does not result in an unprofitable operation. For Scenarios III and V the FCR must rise by $49 \%$ and $62 \%$ respectively to bring the NPV to zero (Fig. 2). Increasing growth rate increases the quota efficiency and profitability. This is an unrealistic scenario as the growth rate used in the base-line calculations is thought to be close to a maximum for wild cod. For ranching, unlike full-cycle farming, selective breeding for faster growth is not possible. However, lower growth rates could be observed if feeding is insufficient or if the fish enter the herds late in the growth period. The sensitivity of growth rate on the profitability of the five scenarios is not completely linear, because even though changes in growth rate have a direct 
influence on the harvesting size of the cod the market price of cod is dependent on the weight of the fish. A $30 \%$ decrease in growth rate does not result in an unprofitable operation (Fig. 3).

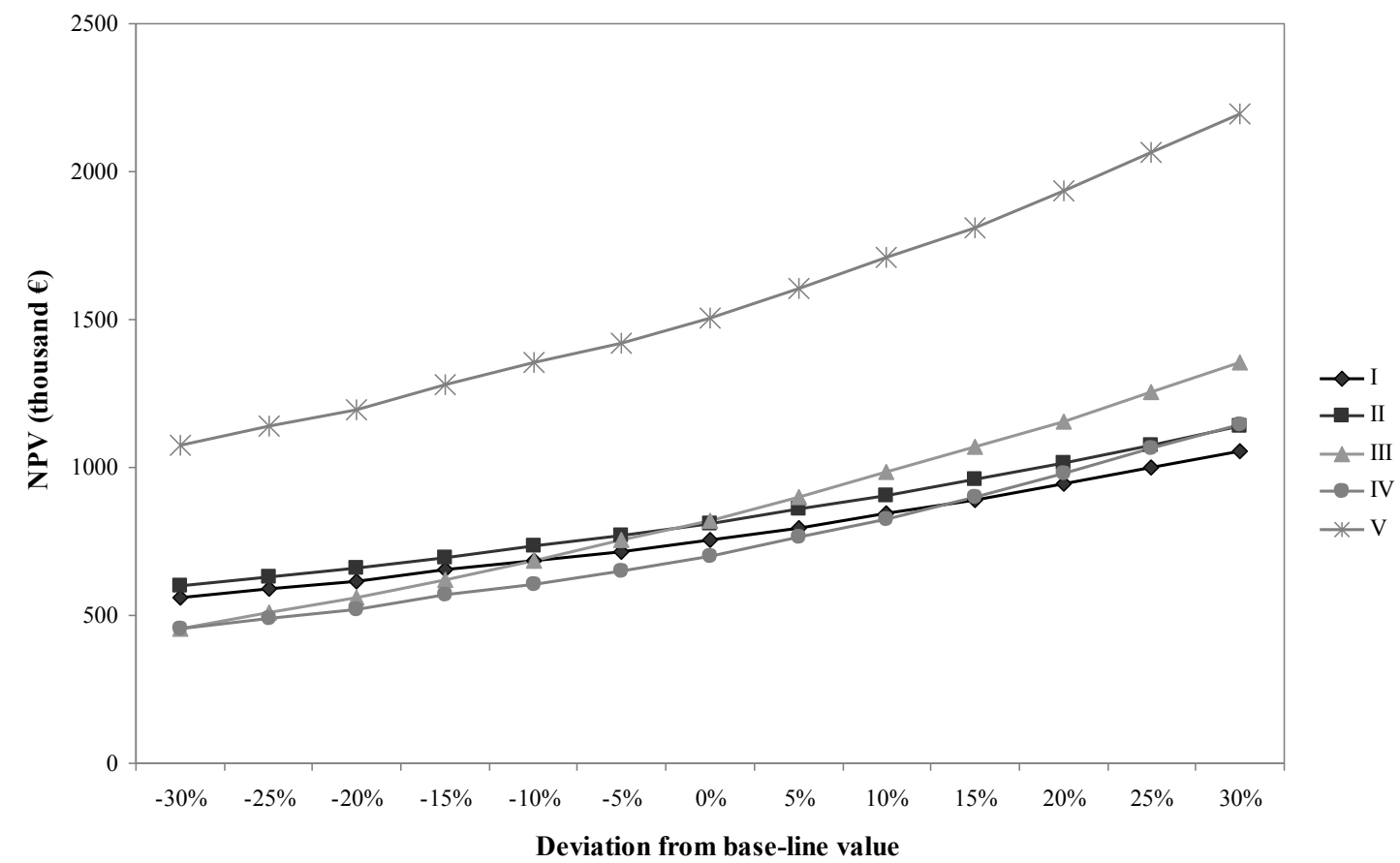

Fig. 3. Sensitivity in NPV to changes in growth rate from the base-line value of $0.48 \%$ per day for the five different scenarios.

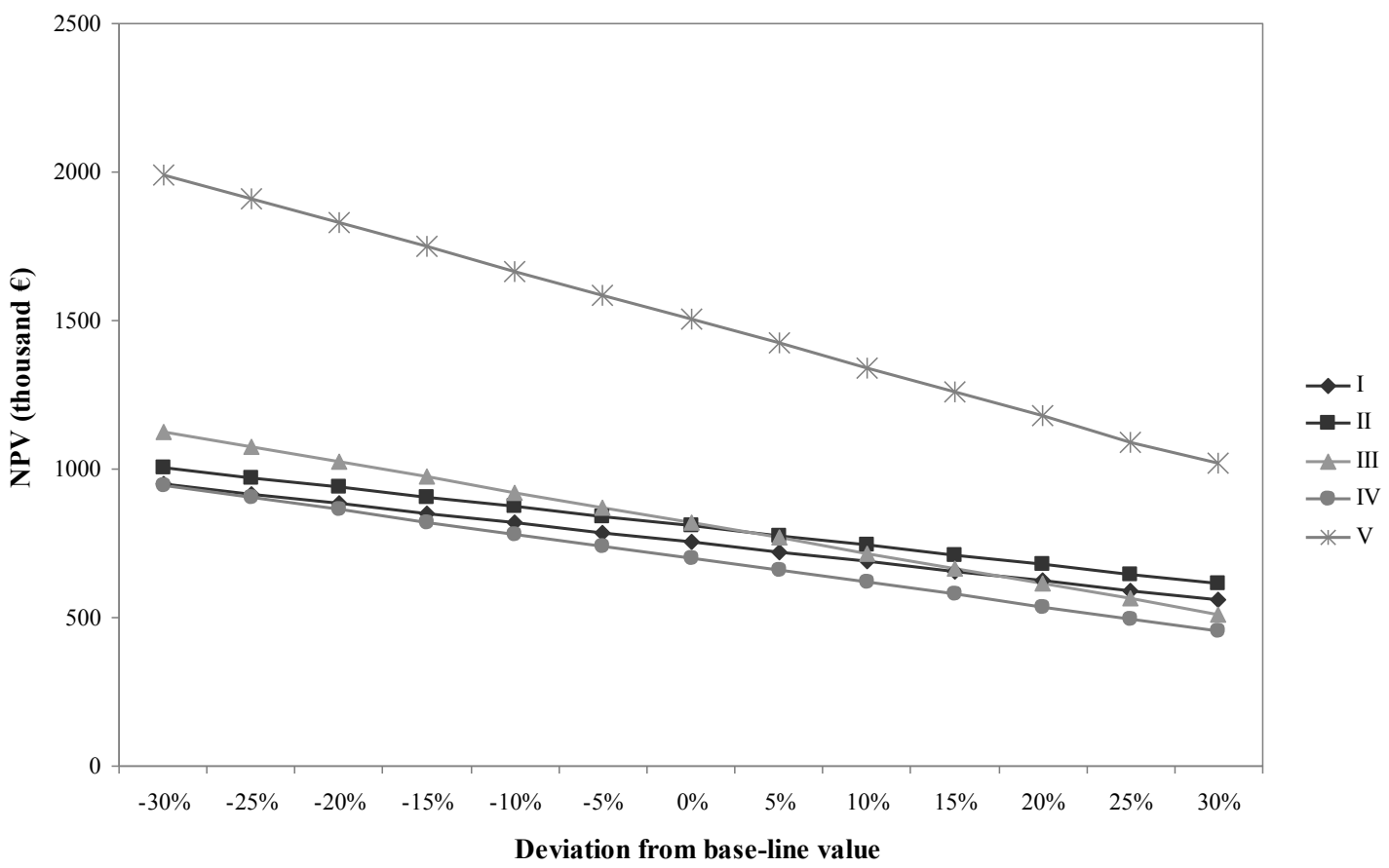

Fig. 4. Sensitivity in NPV to changes in purchasing cost of feed from the base-line value of $0.23 € / \mathrm{kg}$ for the five different scenarios. 
The cost of purchasing feed is approximately $30 \%$ of expenses, but about $20 \%$ comes from transportation and storage of feed which is excluded from the sensitivity analyses. A 30\% increase in feed cost from the base-line value does not result in an unprofitable operation for the five scenarios (Fig 4). The market price of cod in Iceland may to a large extent be determined by supply and demand in the UK and other European countries, the main market for fresh Icelandic cod. Since all revenues generated from cod ranching come from sales of fresh cod, all scenarios are more sensitive to changes in market price than any other parameter in the analyses (Fig. 5). In the initial stages, the supply of ranched cod will be negligible compared to catches of wild cod and thus the profitability is assumed to be independent of harvested biomass. Scenario $\mathrm{V}$, with the greatest biomass of the five options, is most sensitive to changes in market price. For that scenario, a price reduction of $21 \%$ brings the NPV of the operation to zero, but a price increase of about $22-30 \%$ doubles the NPV for all scenarios.

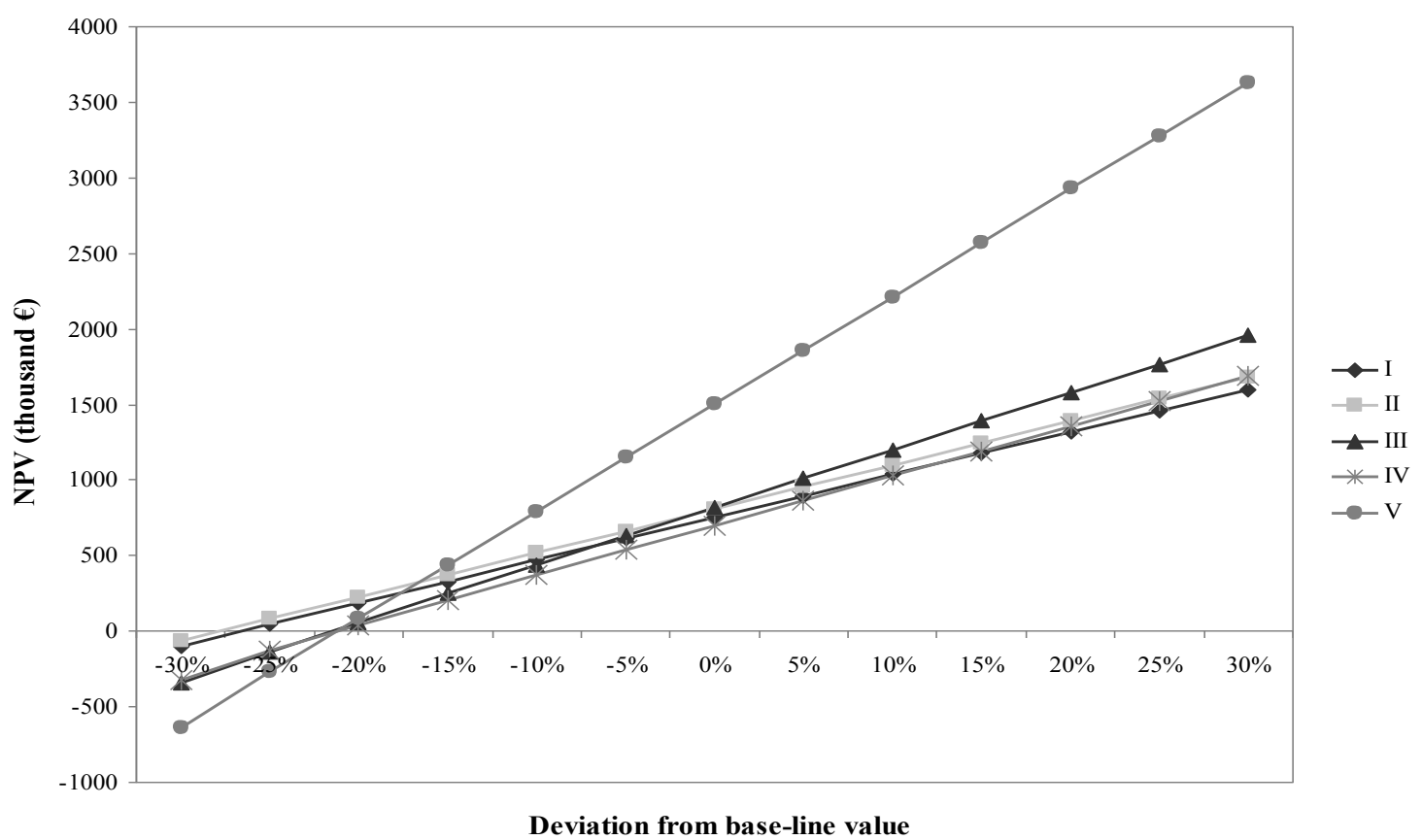

Fig. 5. Sensitivity in NPV to changes in market price of cod from the base-line value of $1.62-2.06 € / \mathrm{kg}$ according to weight for the five different scenarios.

The capture success of ranched cod is perhaps the most critical factor in the feasibility study. The greatest risk of the operation will be if the rancher is unable to catch the fish in which he has invested time and money. In the base-line calculations, it is assumed that all conditioned fish are caught minus 5\% loss due to mortality (Fig. 6). According to the sensitivity analyses, the profitability is slightly less affected by capture success than market price. Scenario V is most responsive, while other scenarios are equally sensitive to capture success of ranched cod. If the rancher catches less than $77 \%$ of the ranched biomass in Scenario $\mathrm{V}$, the operation is unviable. For other scenarios capture success must be above $74 \%$.

\section{Supply of fresh cod}

In Iceland there are seasonal changes in the supply of whole ungutted cod, highest in March and lowest in July, but with only a slight increase in price from May until 
December (Fig. 7a). The export volume of fresh cod fillets was lowest in August and highest in October-December when the price was highest (Fig. $7 \mathrm{~b}$ ). The export volume of cod and haddock fillets more than doubled from the year 2000 until 2006 and decreased by $40 \%$ until 2008, whereas the prices were stable from 2000 to 2005 but increased rapidly from 2005 to 2008 (Fig. 8).

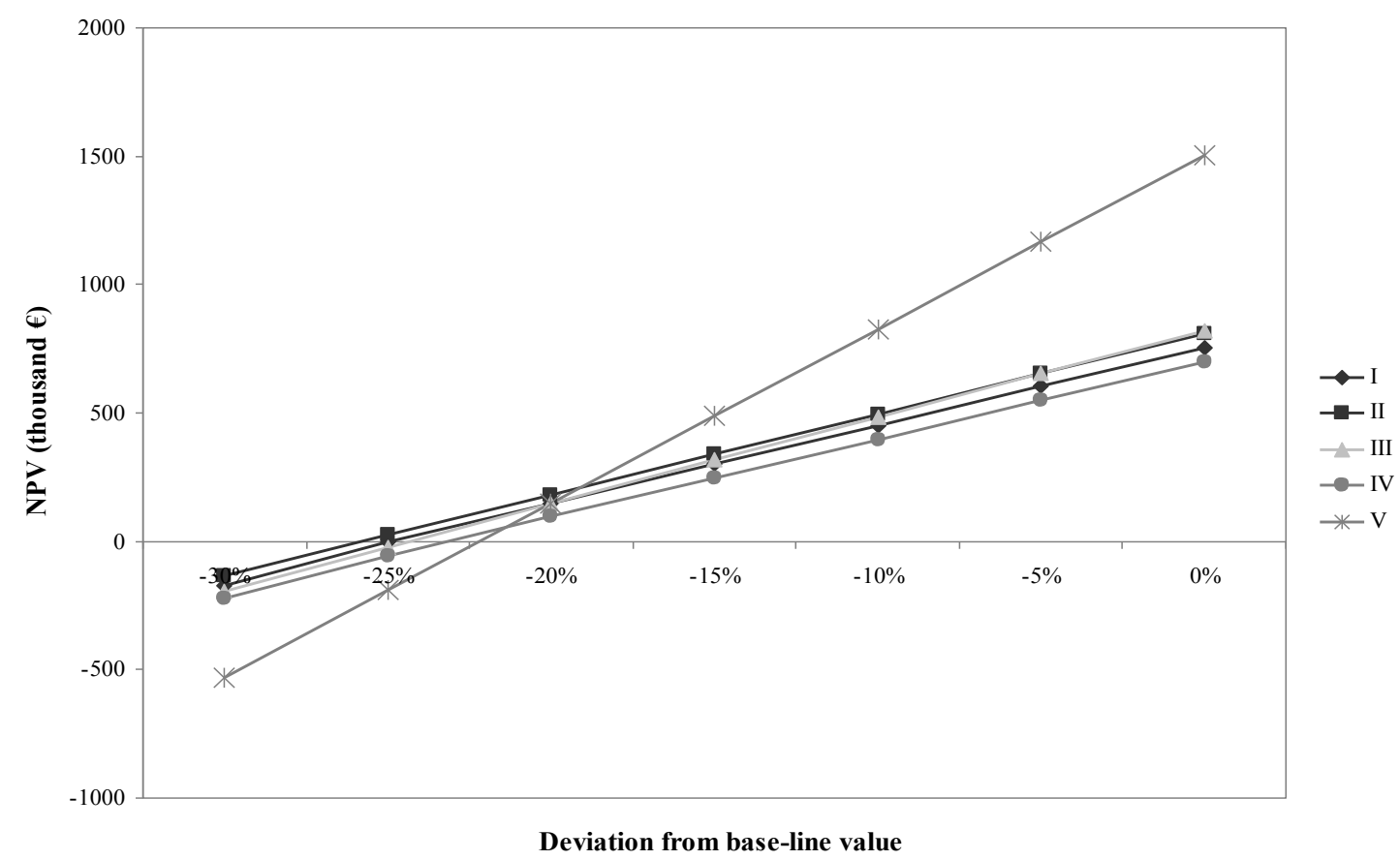

Fig. 6. Sensitivity in NPV to decreases in capture success of conditioned cod from the base-line value of $100 \%$ for the five different scenarios.

\section{Discussions}

For the given assumptions cod ranching was profitable for all five scenarios but the size of the operation seems to have greater effects than the harvesting strategy on the profitability. It is assumed in the calculations that FCR is $3.2 \mathrm{~kg} / \mathrm{kg}$, a value within the range commonly measured for wild cod in sea cages (Gunnarsson et al. 2009) but considerably higher than what was measured for wild cod fed on capelin (FCR = 2.2) under optimal conditions in a laboratory study (Björnsson et al. 2001). The assumed daily growth rate, $0.48 \%$ was based on a large number of cod tagged and recaptured in the herds in Arnarfjördur (Björnsson 2011), a value also within the range commonly measured for wild cod in sea cages (Gunnarsson et al. 2009). The assumptions about feed cost and market price are based on average numbers recorded in recent years. In all cases, it is assumed that the prices of ranched cod are equal to those of wild cod, although farmed cod has in recent years been sold at prices commonly 10-20\% higher (Kjønhaug 2006; Kontali analyse 2008).

Capture success in the herds is, however, the greatest uncertainty in cod ranching. In the Arnarfjördur ranching project, cod tagged in the herds showed high fidelity to their herds from July to October, but already in November they started to show increased migratory behaviour (Björnsson et al. 2010). The capture success will thus depend on the time of harvest but also on how well the herds are fed, the size of the reserved area and the efficiency of the capturing method. For all scenarios, it is 
assumed that purse seining is used to capture cod in the herds. Once the fish have been accumulated in sufficient density in the seine, it is easy to bring them on board with a lift net. In the Arnarfjördur ranching project, a lift net was developed as a stand alone fishing gear to capture cod directly from the herds. It worked perfectly when capturing cod for tagging purposes, but the average daily catch was only 1.0 tons of cod, not enough for the ranching scenarios considered here. So far the method of purse seining has not been tested to capture herds of cod formed by ranching, but it is a well-known method of catching pelagic fish in a cost efficient way and it is hard to think of another fishing method which is more effective and gentle to the fish, although several other capturing methods have also been suggested (Zion et al. 2011; Zion \& Barki 2012). The feeding method accumulates the herd around the feed bag and by hanging a free floating feed bag close to the surface at the time of harvest it should be easy to surround the entire herd with a purse seine. There is precedent for capturing cod with a purse seine in Iceland. In the years 1963-1969 spawning cod was commonly caught with a purse seine off the south coast of Iceland, and in one year the catch was about 40000 tons (Thorsteinsson 1971). Clearly, this method of capturing must be tested and adapted to the prevailing conditions before cod ranching can become an industry.
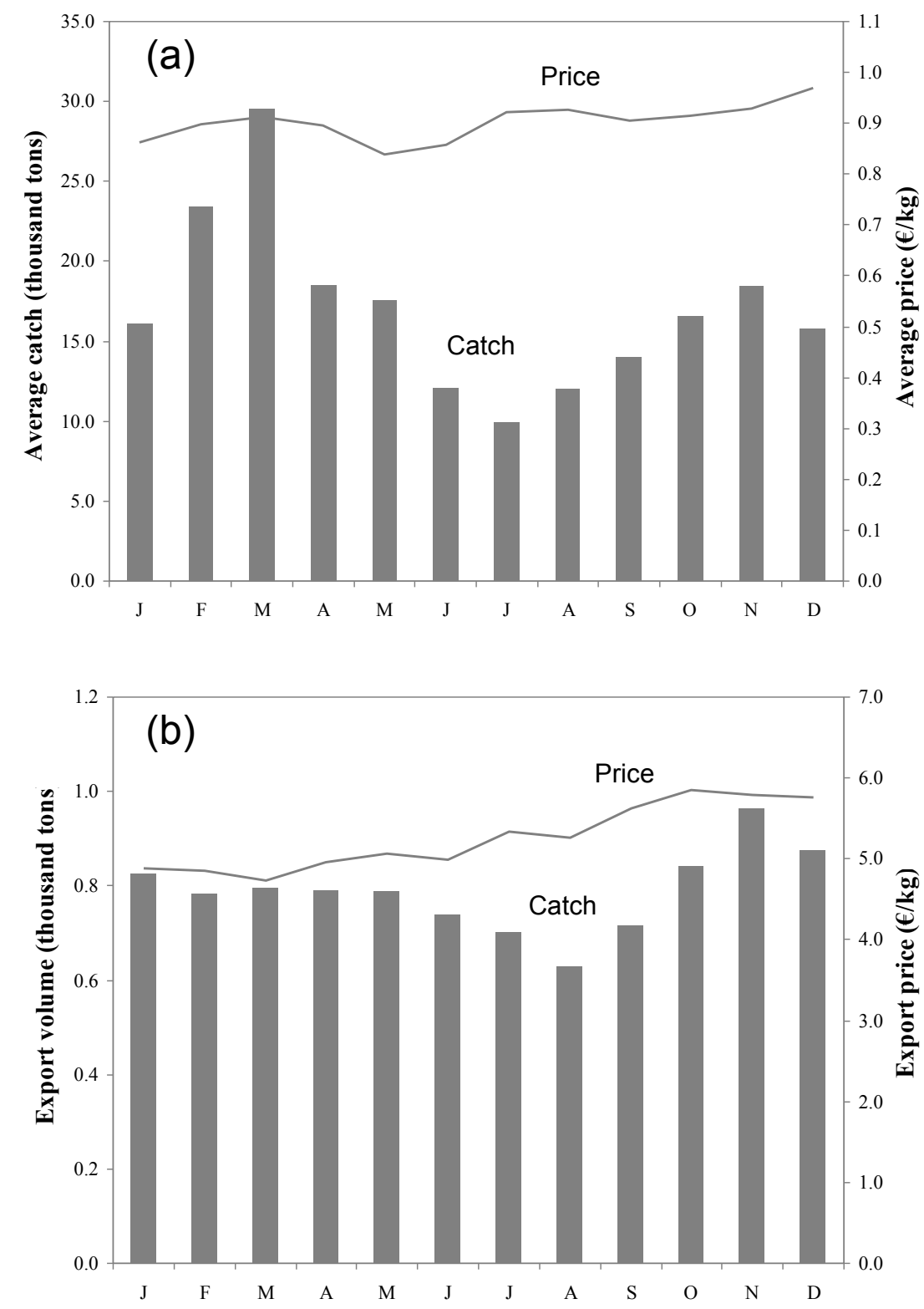
Fig. 7. Seasonal changes in supply and prices of cod in Iceland. (a) Average catches and first-hand prices of whole ungutted cod in Iceland by months for the years 20032007 (Statistics Iceland 2008). (b) Average export volumes and prices of fresh cod fillets by months for the years 2003-2008 (Statistics Iceland 2009).

It is likely that some emigration of conditioned cod from the herds will occurr and some of these will be captured by the commercial fishing fleet. Thus, their additional weight gain resulting from feeding in the herds will be a bonus to the fleet. On the other hand some cod from outside the ranching area will immigrate to the herds during the growth period. As long as there is concensus about the amount of feed given, FCR and quota efficiency, the emigration/immigration may not be a serious problem if the rancher is allowed to catch from the herds the original quota plus the equivalent weight of the additional production created by anthropogenic feeding (Halldórsson et al. 2012).

The NPV is slightly higher for Scenario II than I. The capturing methods of the two scenarios are the same, but size-grading generates more income due to a higher price for the small alive cod sold for on-growing and increased mean size of the large cod increases their market price. On-growing of the small cod by the ranching company, as in Scenario III, increases the NPV, but the higher production cost due to feeding the small cod for a second year results in lower profit margin. However, for the ranching company there are synergistic advantages in on-growing the smallest fish in sea cages, e.g. owing to better yield of the available quota, improved use of vessel and crew and extended harvesting period. Once the harvesting of the herds is completed in the first week of November, the harvesting from the sea cages will begin and continue for the next two months.

By suspending capture until the last two weeks in the growth period, as in Scenario IV, the 200 ton quota gives a maximum yield of the four options. The mean weight of captured cod is therefore higher at the time of harvesting and higher market price ensures greater revenue. But due to the extra cost of chartering a vessel for fishing, this scenario is the least profitable of the four scenarios with a 200 ton quota. There is one additional disadvantage regarding this method. Fishing the herds takes place during a period when the risk of fish leaving the herds is likely to increase. From August to October, cod tagged within the herds were only 30\% as prone to being caught by the commercial fleet, outside the reserved area, as the cod tagged outside the herds, whereas in the following period from November to January the risk was similar (Björnsson et al. 2010). Another possible shortcoming of this method is that the entire biomass, 406 tons, is harvested over only a two week period, or about 200 tons per week. This large quantity may have a negative effect on the market price.

Although Scenario $\mathrm{V}$ requires the largest investments, due to the need to build a freezer, it is the most profitable option, when considering the NPV and the annual net profit. The main objective of this scenario was to find out whether profitability could be increased with larger production. Although the operation requires more manpower, production per man-year is $50 \%$ higher than in Scenario I and $17 \%$ higher than when the herds are allowed to grow to their full potential, as in Scenario IV. However, this operational form is more sensitive to changes in the most relevant factors concerning the operation, such as capture success and market price. 
In the five scenarios the capturing in the herds is assumed to be highly seasonal. In most scenarios the entire catch is expected to be caught within a nine week period, and in one scenario during a two week period (Scenario IV). Cage based fish farming is better equipped to adapt to the market environment, where production can be aimed to supply a quality product at the right time. In ranching it would be possible to start harvesting during the summer, if the rancher is prepared to settle for a lower mean weight of the catch and therefore less value. Lengthening the harvesting period beyond early November is not a feasible option because of increased risk of fish leaving the herds in November-January, unless sea cages are used in conjunction with cod ranching as discussed before.

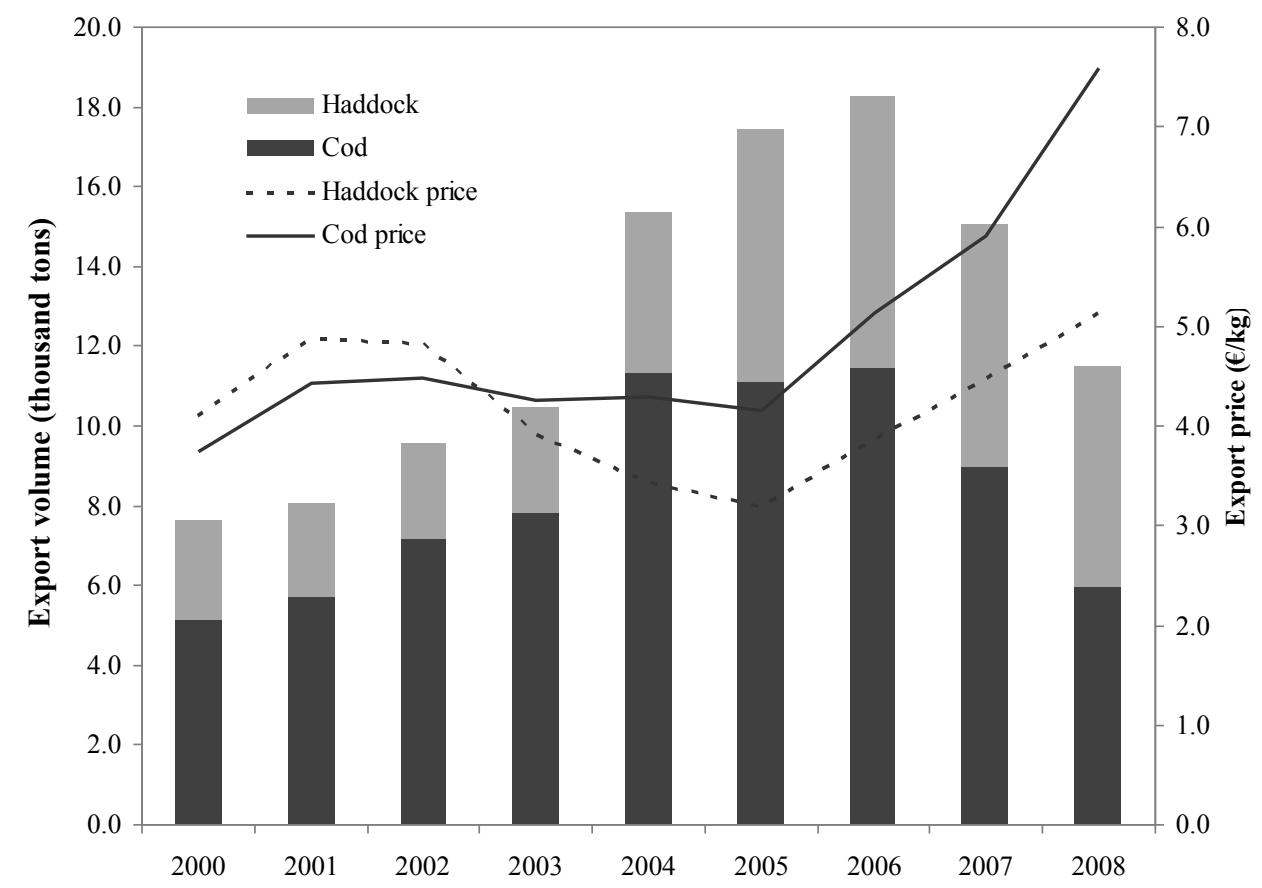

Fig. 8. Yearly quantities and prices of exported cod and haddock fillets for the years 2000-2008 (Statistics Iceland 2009).

Considerable amounts of fresh white fish are exported from Iceland to Europe. The main products are fresh cod and haddock (Melanogrammus aeglefinus (L.)) fillets and iced whole fish (Ministry of Fisheries and Agriculture 2008). Despite the short harvesting time in cod ranching, the timing is good with respect to demand for fresh cod. During September-October, the period when most of the herdfish is harvested, there is a high demand for fresh cod and the prices are close to a maximum. A recent study implies that the market price of fresh cod fillets is highest in the fourth quarter of the year in USA and Belgium (Gudjónsson et al. 2006).

The feasibility study indicates that cod ranching can be a profitable industry in the future, although it is likely to be controversial. Cod ranching can enhance quota efficiency with minimal investment compared to cage-based farming (Halldórsson et al. 2012). However, the method requires a large reserve area around the feed stations to prevent poaching (Björnsson 2011) which may limit the fishing rights of other fishing companies. This may require ranching to pay higher resource rent compared to conventional fishing. If ranching is more profitable than traditional fishing and farming (Halldórsson et al. 2012) and can increase the total revenue and 
net profits from the fish stocks, the legislature must consider these ideas with an open mind. At least, these promising results should be an impetus to further research and development of cod ranching as it may be a way to maximize the resource rent of the stock.

The study indicates that cod ranching will benefit greatly from economies of scale. With the cooperation of fishermen, fishing companies and fish processors, ranching could be conducted on a far greater scale than is examined here. Such cooperation would not have to be limited to one fjord since whole regions could be included in a ranching programme. The suggested implementation of the idea is that inshore waters would be reserved for a ranching programme where local fishermen would take care of feeding in their area. A specialized well-boat would capture the cod from the herds, sort them into sizes, bring the smallest fish to on-growing farms and transport the larger fish to a slaughterhouse for processing. The idea of large scale feeding of the Icelandic cod stock has already been proposed (Björnsson 2001).

Ranching of cod and other marine species can perhaps be described as a mixture of aquaculture and capture based fisheries. Aquaculture can offer important advantages of controllability, ownership rights and responsibilities, and market adaptation (Anderson 2002). The future may see greater integration of the aquaculture and marine fisheries sector (Muir \& Young 1998; Asche 2008; Bostock et al. 2010). While ranching doesn't have as much controllability and ability to adapt to markets as aquaculture, it probably has the upper hand concerning these factors when compared to commercial fishery. Further research must be carried out to develop fish ranching, preferably on a greater scale and over a longer period than was possible in the Arnarfjördur project. Simultaneously, the social, political and legal aspects of the idea must be studied to see how it could fit within the existing legal framework and what would be the best way to initiate such an industry and how it could be integrated with commercial fisheries and aquaculture. Although intensive aquaculture will continue to grow globally, well managed fish stocks will always be an important food source for mankind and thus ranching, which basically is a quota multiplier, can increase this food supply, potentially at competitive prices.

\section{Acknowledgments}

We would like to thank Mr. Valdimar Ingi Gunnarsson, MRI, for useful suggestions concerning the manuscript, Mr. Jón Thórdarson, Ródur Ltd., for valuable suggestions about the implementation of cod ranching and Mr. Sindri Sigurdsson, Síldarvinnslan Ltd., Mr. Kristján G. Jóakimsson, Hradfrystihúsid-Gunnvör Ltd., Mr. Sindri Vidarsson,Vinnslustödin Ltd., and Mr. Jóhannes Pálsson, Aker Seafoods ASA, for providing various information regarding operating costs. The Icelandic Technology Development Fund financed the study. Two anonymous reviewers made some useful suggestions.

\section{References}

Aasjord H. \& Hansen T. (2006) Live catch on board a small fishing vessel. Sintef Fiskeri og havbruk AS. Rapportnr. SFH80 A0633022. [In Norwegian]

Anderson, J.L. (2002) Aquaculture and the future: why fisheries economists should care. Marine Resource Economics 17, 133-152.

Asche, F. (2008) Farming the sea. Marine Resource Economics 23, 527-547. 
Björnsson B. (1999) Fjord-ranching of wild cod in an Icelandic fjord: Effects of feeding on nutritional condition, growth rate and behaviour. In: Stock enhancement and sea ranching (ed. by B.R. Howell, E. Moksness \& T. Svåsand), pp. 243-256. Fishing News Books, Blackwell Science, Oxford.

Björnsson B. (2001) Can fisheries yield be enhanced by large-scale feeding of a predatory fish stock? A case study of the Icelandic cod stock. Canadian Journal of Fisheries and Aquatic Sciences 58, 2091-2104.

Björnsson B. (2002) Effects of anthropogenic feeding on the growth rate, nutritional status and migratory behaviour of free-ranging cod in an Icelandic fjord. ICES Journal of Marine Science 59, 1248-1255.

Björnsson B. (2011) Ranching of wild cod in 'herds'formed with anthropogenic feeding. Aquaculture 312, 43-51.

Björnsson B., Steinarsson A. \& Oddgeirsson M. (2001) Optimal temperature for growth and feed conversion of immature cod (Gadus morhua L.). ICES Journal of Marine Science 58, 29-38.

Björnsson B., Steinarsson A. \& Árnason T. (2007) Growth model for Atlantic Cod (Gadus morhua): Effects of temperature and body weight on growth rate. Aquaculture 271, 216-226.

Björnsson B., Karlsson H. \& Thorsteinsson V. (2010) Effects of anthropogenic feeding on the migratory behaviour of coastal cod (Gadus morhua) in Northwest Iceland. Fisheries Research 106, 81-92

Blaxter J.H.S. (2000) The enhancement of marine fish stocks. Advances in Marine Biology 38, 1-54.

Bostock, J., MacAndrew, B., Richards, R., Jauncey, K., Telfer, T., Lorenzen, K., Little, D., Ross, L., Handisyde, N., Gatward, I. \& Corner, R. (2010) Aquaculture: global status and trends. Philosophical Transactions of the Royal Society 365, 2897-2912.

Central Bank of Iceland (2009) Currency exchange rates. Retrieved February 4, 2009 from Sedlabanki: http://www.sedlabanki.is/default.aspx?PageID=7.

Doherty P.J. (1999) Recruitment limitation is the theoretical basis for stock enhancement in marine populations. In: Stock enhancement and sea ranching (ed. by B.R. Howell, E. Moksness \& T. Svåsand), pp. 9-21. Fishing News Books, Blackwell Science, Oxford.

Gonzalez E.B., Umino T. \& Nagasawa K. (2008) Stock enhancement programme for black sea bream, Acanthopagrus schlegelii (Bleeker), in Hirosima Bay, Japan: a review. Aquaculture Research 39, 1307-1315.

Gudjónsson E.B., Benediktsson H.C., Gylfason H.F., Arason S. \& Margeirsson S. (2006) Seasonal fluctations in price of cod products and market gains by traceability in fisheries sector. Icelandic Fisheries Laboratories, Reykjavík. IFL Report 28-06. [In Icelandic]

Gunnarsson V.I., Björnsson B., Grétarsson E.H., Kjartansson H., Pálsson J.Ö., Elíasson K., Haraldsson Ó.H., Sigurdsson S., Ásgeirsson S.Th. \& Ólafsson, Th. (2009) Cod quota for on-growing: results for the year 2007. Marine Research Institute, Report Series no. 144. [In Icelandic]

Halldórsson J.E., Björnsson B. \& Gunnlaugsson S. (2012) Feasibility of ranching coastal cod (Gadus morhua) compared with on-growing, full-cycle farming and fishing. Marine Policy 36, 11-17..

Kitada S. \& Kishino H. (2006) Lessons learned from Japanese marine finfish stock enhancement programmes. Fisheries Research 80, 101-112. 
Kjønhaug A.F. (2006) Marine fish. In:Kyst og havbruk 2006 (ed. by T. Svåsand, K. Boxapen, E. Dahl \& L.L. Jørgensen), pp. 134-136. Fisken og havet, særnr. 2. [In Norwegian]

Knútsson B. (1997) Farming of cod in Iceland: a feasibility study of farming cod in a land based facility, sea pens, and by ranching in a fjord. MSc. Thesis, University of Iceland, Reykjavík. [in Icelandic]

Kontali analyse (2008) Monthly cod report. No. 10, October 2008. Kontali analyse AS (www.kontali.no). 44 pp. + Appendix.

Lorenzen K. (2005) Population dynamics and potential of fisheries stock enhancement: practical theory for assessment and policy analysis. Philosophical Transactions of the Royal Society B 360, 171-189.

Ministry of Fisheries and Agriculture (2008) Fresh (fish). Retrieved March 27, 2009 from Icelandic fisheries: http://www.fisheries.is/products/processingmethods/fresh/

Muir J.F.\& Young J.A. (1998) Aquaculture and Marine Fisheries: Will Capture Fisheries Remain Competitive. Journal of Northwest Fisheries Science 23, 157174.

Statistics Iceland (2008) Afli, verdmæti afla og medalverd eftir tegundum löndunar og fisktegundum 2003-2007 (catch, value of catch and average price according to types of landings and species of fish). Retrieved March 14, 2009, from Statistics Iceland: http://www.hagstofa.is/?PageID=145\&src=/temp/Dialog/varval.asp?ma=SJA0 9031\%26ti=Afli\%2C+ver\%F0m\%E6ti+afla+og+me\%F0alver\%F0+eftir+tegund +1 \%F6ndunar+og+fisktegundum+2003\%2D2007++\%26path=../Database/sjavarut vegur/af3Londun/\%26lang=3\%26units=Tonn $/ 1.000 \% 20 \mathrm{kr} \%$ F3nur $/$ per $\% 20 \mathrm{k} \% \mathrm{E}$ $\mathrm{dl} \% \mathrm{~F} 3$.

Statistics Iceland (2009) Úflutningur sjávarafurda eftir afurdaflokkum, vinnslugreinum og löndum 1999-2007 (export of seaproducts according to types of product, processing and countries). Retrieved March 4, 2009, from Statistics Iceland: http://www.hagstofa.is/?PageID=149\&src=/temp/Dialog/varval.asp?ma=SJA0 4903\%26ti=\%DAtflutningur+sj\%E1varafur\%F0a+eftir+afur\%F0aflokkum\%2C+ vinnslugreinum+og+1\%F6ndum+1999\%2D2007+++\%26path=../Database/sjavar utvegur/utf/\%26lang $=3 \% 26$ units $=\mathrm{kg} / \% 20 \mathrm{ISK}$

Svåsand T., Kristiansen T.S., Pedersen T., Salvanes A.G.V., Engelsen R., Nævdal G. \& Nødtvedt M. (2000) The enhancement of cod stocks. Fish and Fisheries 1, 173205.

Thorsteinsson G. (1971) Description of commercial Icelandic purse seines for herring, capelin and cod. In: Modern fishing gear of the world, 3 (ed. by H. Kristjánsson), pp. 217-225. Fishing News Books, London.

Verdlagsstofa skiptaverds (2008) Fallsamband fyrir óslægdan thorsk (price of ungutted cod as a function of weight). Retrieved December 5, 2008 from Verdlagsstofa skiptaverds: www.verdlagsstofa.is

Westfjord Power Company Ltd. (2008) Verdskrá - Raforkusala (price of electricity). Retrieved December 19, 2008 from Orkubú Vestfjarda ohf: http://www.ov.is/ov/upload/files/verdskrar/verdskra_ov_010708_sala.pdf

Zion, B. \& Barki, A. (2012) Ranching fish using acoustic conditioning: Has it reached a dead end? Aquaculture 344-349, 3-11. 
Zion, B., Barki, A., Grinshpon, J., Rosenfeld, L. \& Karplus, I. (2011) An automatic fishing machine based on acoustic conditioning. Aquacultural Engineering $45,87-91$. 
